\title{
ETHICAL CODES AND THEIR IMPORTANCE IN THE MODERN MANAGEMENT PROCESSES
}

\section{MARCIN JANOWSKI}

University of Szczecin, Faculty of Management and Economics of Services, POLAND

e-mail: marcin.janowski@wzieu.pl

\begin{tabular}{l|l}
$\begin{array}{l}\text { RECEIVED } \\
\text { ACCEPTED } \\
\text { JEL } \\
\text { CLASSIFICATION }\end{array}$ & $\begin{array}{l}18 \text { January } 2018 \\
2 \text { September } 2018\end{array}$ \\
A10, D63 & ethics, business ethics, ethical codes, management process \\
KEYWORDS & $\begin{array}{l}\text { The modern ethical considerations are becoming an increasingly important topic in society and economy. } \\
\text { The creation of an ethical image of a company may result in benefits, improve management, and eliminate } \\
\text { conflict situations. The presented tools of effective management are only a part of those offered by employing } \\
\text { ethical codes in business. Therefore, it seems reasonable to combine tangible and intangible-ethical gains in } \\
\text { order to achieve economic benefits. }\end{array}$
\end{tabular}

\section{Introduction}

The ethical aspect of economic life has been known to people since the first time they decided to exchange and offer their goods to other people. Moral standards apply to contemporary managers, entrepreneurs and sellers in the same way as they once applied to traders or bankers. This could be proved by numerous examples of trade corporations and craft guilds created as early as in the ancient time and the Middle Ages, which required from their 
members to be honest, reliable, and hard working. The aim was to not only shape the appropriate moral stance of a person, but also multiple profit by displaying such attitude. This was either because such conduct made it possible for affiliated producers and traders to distinguish themselves from unreliable traders and ordinary frauds. This ancient demeanour, which is represented in, among others, mercantile ethos, remains valid in today's economic realities. However, it should be added that the equivalent of a merchant of that time, i.e., today's entrepreneur, must perform disproportionately more moral duties than his precursor (Hartman, Woleński, 2009, p. 316). This is due to economic evolution and emphasis on creating a democratic society in which individuals are equal. Therefore, a modern representative of, e.g., a bank, should not only be honest and reliable, but also possess other features, e.g. express the same level of respect for all customers, regardless of their wealth, origin or social status.

\section{Characteristics of ethics, business ethics, management}

The explanation of the concept of ethics should be preceded by the discussion on morality, as although these two words are often used interchangeably, they do not bear the same mining. The word morality derives from Latin mores, which in literal translation means custom, tradition or a body of standards or principles that should be followed by a person. Whereas, ethics, which is freely translated in the same way (the word ethics derives from the Greek word ethicos), is "a science dealing with philosophical and religious reflections, which are aimed at answering questions about the character and nature of values referred to as Good and Evil" as stated by B. Pogonowska (2004, pp. 38-39). The above-stated definition includes element defined as spiritual reflection, which is of particular importance. This is because religion is considered one of the most important determinants of ethics, while religious norms have the strongest influence on understanding of good or evil by social groups. It should be noted, however, that in this case, atheism is another type of spiritual reflection. To sum up, ethics may be described as the science of morality.

The concept of business ethics is variously defined, and therefore, before presenting its definitions, the author decided that it is worth preceding them with an attempt to define the very concept of business, which may be important for its ethical evaluation. When considering ethical codes, the opinion presented by P. Czarnecki, according to whom "the goal of business is to satisfy the material (and indirectly also spiritual) human needs of both present and future generations" (Czarnecki, 2008, p. 196) seems to be the right approach. This view is supplemented by the assumption that "satisfying material needs, or maximizing profit, should not be the only or the most important criterion of the entrepreneur's activity, as it is not of the highest value", as presented by J.W. Gałkowski (Borkowski, Gałkowski, 2002, p. 42). Therefore, for the purpose of further consideration of the role of ethics and ethical codes, it is assumed in this article that absolute profit maximization does not constitute a priority, even though profit is essential to the functioning of a business. An important condition for business operation must be ethical relationships that should take place between an entrepreneur and an employee, an entrepreneur and a client, an employee and a client, as well as an entrepreneur and state and society (the environment).

This way of characterizing business makes it possible to define business ethics itself, which in the literature is referred to as "the systematic study of ethical matters (beliefs, standards, values, etc.) pertaining to business, industry, banking, and related activities, institutions, or, in general, practices of human behaviour. (Gasparski, 2000, p. 17). The concept of business ethics may also be presented from the perspective of management, i.e., maximization of profits, as portrayed by W. Gasparski: "Business ethics is a discipline practiced at the interface of ethics, understood as a branch of practical philosophy, and managerial activity related mainly to the economy, 
trade and other types of business activities" (Gasparski, 2000, p. 16). The characteristics of business ethics is proof of the necessity to revaluate goals of many contemporary entrepreneurs, and understand that the aim of a company should be such profit maximisation that does not violate freedom of other participants involved in management and is in accordance with the view presented by A.N. Whitehead, who said that "Great societies are societies in which business people attach great importance to their deeds and functions." (Gasparski, 2000, pp. 18-19).

Whereas, the economic literature most often presents management as a process that is constantly repeating itself and involves maximizing profits. It should be added that profit maximization does not always involve maximisation of tangible assets, but may also be perceived through building positive relationships with the environment, in particular with clients. This is especially important for today's global, toughly competitive markets. The aspect of management may be also presented in the same way as the one of M. Rekowski, who defined management as making economic choices on what to allocate relatively rare resources available to a person and needs which should be met. Every economic decision is related to two aspects: positive and negative. Whereas, "the positive aspect concerns making decisions on what economic goals will be pursued and what resources will be used to achieve these goals, the negative aspect means the necessity of resigning from other goals to which resources could be allocated" (Rekowski, 2009, p. 14). It is worth noting that from the perspective of business ethics, the decisions making process should not be limited to only an economic but also a social aspect.

\section{The concept and structure of ethical codes}

The aim of specialists in business ethics is to raise the ethical awareness of the organization in such a way, as to facilitate the management process, affect the positive image of the company, or eliminate unwanted behaviours. These goals can be achieved by means of tools such as the selection system, the recruitment system, training courses for employees, and the use of ethical codes.

Ethical codes may be defined as a written or oral set of standards of conduct, values, practices and principles that are required to be followed by recipients of codes. The importance of codes is proven by the fact that even in organizational groups that were morally ambiguous, there was a need to create a set of rules, standards of conduct, prohibitions and sanctions. The above relates to pirates, who are considered pioneers of codes (Bugdol, 2007, p. 163). However, their behaviour is not a good example to follow, as the guiding principle of codes is to follow them in order not to hurt or harm others. Nevertheless, this example shows that in a situation where people have to coexist and cooperate, guidelines on how such cooperation should take place are needed.

Codes can be divided into two types:

- general, which are addressed to representatives of a professional group, e.g. the code of medical ethics, the civil servants' ethical code, etc.,

- specific, which regulate the organizational group's activities specialized in a particular field, e.g., the code of ethics for veterinarians, the code of ethics for tax office or city hall.

The structure of most ethical codes consists of the following elements: introduction, formulation of general principles, definition of more detailed rules, description of ways of resolving conflict situations, and determination of sanctions (however not in all codes) imposed on a person or group of people who do not comply with the rules contained in ethical code.

Furthermore, ethical codes should shape employees' attitude based on five pillars of ethical behaviour, which include responsibility for themselves and others, commitment, professionalism, teamwork and respect (Vissak, 
Vadi, 2013, p. 114). Such ethical codes have a chance to succeed in economic space, and bring the enterprise broadly understood profit maximization in economic and social sense.

\section{The role of ethical codes in the contemporary economic realities}

Are ethical codes truly needed in economic realities, if there exist law codes? This is a question the supporters of the existence of ethics in the economic environment are frequently asked. The truth is that law norms, i.e., the commercial and employment codes, regulate many aspects of economic life. Furthermore, it is also true that nowadays it is not possible to operate freely (manage) only in environments regulated by strict standards of conduct, which are defined as the codes of law. Therefore, the opening question may be answered with a different one, i.e., are all behaviours, according to the law, acceptable, moral behaviours? The answer is negative, and therefore the law should be supported with soft standards, called ethical standards. This is because any law cannot regulate all aspects of economic life, as by nature it has to be universal and thus simple. Each branch of the economy or sector has its own specific features, which is why it requires establishing its own additional rules of proper conduct. Moreover, the rules of conduct vary depending on social environment or place (an act that is acceptable in Europe, may not be seen in that way in, for example, Africa). A law whose task is to regulate all these aspects would become complicated, unclear and too extensive to apply. Therefore, apart from the law, the application of principles of professional ethics as a complement to management process seems to be the right choice. (Mączyńska, Sójka, 2017, pp. 141-143). The goals of the law and ethical codes coincide and concern eliminating pathological behaviours in the form of crimes or financial frauds ${ }^{1}$. As proof, it is important to underline that financial fraud is defined in the literature on the subject as not only punishable, but also unethical or unacceptable act in the economic sphere. To quote Z. Monkiewicz and Z. Nizińska: "financial frauds (in a broad sense) are punishable acts that affect and threaten universal goods in the sphere of economic life, violate trust related to the position of the perpetrator or institution of economic life, and attribute to a loss in public trust in the economic system or its basic institutions." (Monkiewicz, Nizińska, 2013, p. 1). The problem of financial frauds and irregularities in the management process concerns almost every other company, especially those operating in the field of service activities. The reason for this state of affairs may be the intangible nature of services, where it is easy to disobey the principles of proper conduct, and, at the same time, more difficult to prove such behaviour. Therefore, the role of ethical codes seems especially important here. The development and application of an appropriate set of standards of conduct in a complementary manner will complement the law codes and allow offering services of a satisfactory standard.

The problem of malpractice and financial frauds also concerns Poland. The research conducted by PwC consulting company in 2018 showed that $50 \%$ of companies and organizations were subject to economic pathologies. The largest percentage of all crimes concerns asset misappropriation - as much as $46 \%$, with the following being: unethical ways of conducting business and conflict of interest (43\%), transactional and tax frauds (40\%), cybercrime (33\%) and bribery and corruption (17\%) (PWC, 2018).

Polish entrepreneurs estimate that financial loss incurred as a result of malpractice and financial frauds significantly concerns as many as $43 \%$ of them, with the sums ranging from PLN 400 thousand to PLN 20 million.

\footnotetext{
${ }^{1}$ Pathological behaviour in management processes is defined as economic pathology. The word pathology derives from the Greek language and is a combination of two other words: phatos (suffering), logos (science). Originally, the word pathology was used in medicine. Nowadays, economic pathologies are defined as destructive and self-destructive behaviors of people, social groups or whole societies functioning in the economic environment.
} 
Unfortunately, these are not the only costs incurred as a result of the occurrence of economic pathologies. According to the research, as many as $58 \%$ of entrepreneurs indicated the negative influence of malpractice and financial frauds on employee morale, $51 \%$ experienced noticeable deterioration of business relations with the environment, and $48 \%$ of the entrepreneurs had their company's reputation, that is, the strength of the company's brand, negatively affected (PWC, 2018).

Thanks to the creation of ethical codes, the scale of the pathological behaviours presented above can be can significantly reduced in business ethics. The advantages of using ethical codes include, among others:

- impacting the prestige of the organization,

- helping solving interpersonal conflicts on many levels,

- hastening the decision-making process,

- defining and justifying the limits of deviations from legal norms,

- impacting the development of local communities and the natural environment,

- impacting cooperation with contractors,

- ethical codes may be treated as an effective way of completing internal and external control of employees, e.g. in public administration (Gasparski, Jabłońska-Bonca, 2009, p. 223).

All these advantages have a direct impact on the management process, that is, making decisions about maximizing profits in the enterprise. Since ethical codes affect the image of the company and facilitate management, they can be included in the assets of the organization (Gasparski, 2000, p. 192). Furthermore, introduction of ethical codes is an essential element of creation and raising organizational culture, which is defined as "a set of dominant values and standards of conduct, characteristic for a given organization, that are supported by assumptions about the nature of reality, manifested through artefacts - external artificial constructs of a given culture ... which are norms and values of a given organization" (Siwek, 2000, p. 365). The presented concept of organizational culture shows what types of relations ethical codes may be based on, i.e., interpersonal relations, the nature of the organization itself, the nature of the environment, and the relationship of the organization with this environment.

The above-presented premises and research results clearly indicate that codes can be used in modern management, and that they are also an indispensable supplement to the codes of economic law, which can reduce the scale of economic pathologies in Poland and in the world.

\section{Conclusions}

The role of codes is to show directions to the participants of economic processes, in such way so that they can find in them clear indications as to the correct behaviour in relation to individual sectors and industry branches. Paradoxically, the most important advantage of using ethical codes in enterprises, that is, indicating the right course of action, carries a certain risk. This is due to the fact that ethical codes should not be treated as universal standards, but only complementation to general ethics. Moreover, people who follow the principles included in codes, often erroneously believe that in order to act properly, one needs to be ethical in accordance with the code. A perfect example of this may be a situation when a police officer, who acts professionally only during working hours, is a witness to crime. The officer may assume that he has the right to react only when on duty, as after it he is discharged from this obligation (the code may not specify the scope of responsibilities off the duty). Meanwhile, one is a professional 24 hours a day, and so there are many examples of police officers "in civilian clothes" who reacted to violence and crime. 
It is worth noting that although the need to apply ethics in the form of codes seems to be indispensable in the management process, their application is not easy, if only due to the existence of high pressure not to do so. If the recipients of the codes are to follow them, they should be created on the basis of the five principles of ethical power. This is the concept of the five elements that were described in the book by K. Blanchard and N.V. Peal and which include: purpose, pride, patience, persistence and perspective (Blanchard, Peale, 2010, p. 47). The application of the principle of five elements of ethical behaviour allows creation of permanent rules of proper conduct and helps applying them, especially in crisis situations. The ethical codes of modern enterprises remind of and defend the goal to increase the long-term value of economic entities, because, as K. Jajuga wrote: "short-termism destroys the market system" (Jajuga, 2017, p. 25). Ethical codes are becoming increasingly more important nowadays. Strongly competitive markets require internal regulations in the field of management, especially in large corporate entities.

\section{References}

Bauman, Z. (2007). Szanse etyki w zglobalizowanym świecie. Kraków: Wydawnictwo Znak.

Blanchard, K., Peale N.V. (2010). Etyka biznesu. Warszawa: Wydawnictwo Studio Emka.

Borkowska, M., Gałkowski, J.W. (eds.) (2002). Etyka w biznesie. Lublin: Towarzystwo Naukowe KUL.

Bugdol, M., (2007). Gry i zachowania nieetyczne w organizacji. Warszawa: Difin.

Czarnecki, P. (2008). Dylematy etyczne współczesności. Warszawa: Difin.

Gasparski, W. (2000). Wykłady z etyki biznesu. Warszawa: Wydawnictwo Wyższej Szkoły Przedsiębiorczości i Zarządzania im. Leona Koźmińskiego.

Gasparski, W., Jabłońska-Bonca, J. (eds.) (2009). Biznes, Prawo, Etyka. Warszawa: Wydawnictwo Akademickie i Profesjonalne.

Hartman, J., Woleński, J. (2009). Wiedza o etyce. Bielsko-Biała: Park Edukacja.

Jajuga, K. (2017). Inwestycje społecznie odpowiedzialne. Kariera w Finansach i Bankowości 2016/17. Retrieved from: www. karierawfinansach.pl.

Monkiewicz, Z., Nizińska, Z. (1993). Wybrane problemy regulacji prawnej przestępczości gospodarczej, Report No. 54. Warszawa: Wydział Ekspertyz Prawnych Biura Studiów i Ekspertyz Kancelarii Sejmu.

Pogonowska, B. (ed.) (2004). Elementy etyki gospodarki rynkowej. Warszawa: PWE.

PwC (2018). Pulling fraud out of the shadows. Global Economic Crime and Fraud Survey 2018. Retrieved from: https://www.pwc.com/ gx/en/forensics/global-economic-crime-and-fraud-survey-2018.pdf.

Rekowski, M. (2009). Mikroekonomia. Poznań: Wrokopa sp. z 0.0.

Siwek, J. (2002). Znaczenie kodeksu pracownika w procesie zmian kulturowych w Poczcie Polskiej. IX Sympozjum Poczty Polskiej „Operatorzy narodowi na europejskim rynku pocztowym - doświadczenia i perspektywy”. Szczecin: Zapol.

Sójka, J. (2017). Etyka i ekonomia. Rozważania o Instytucjonalnym modelu etyki gospodarczej. In: E. Mączyńska, J. Sójka (eds.), Etyka i ekonomia. Warszawa: Polskie Towarzystwo Ekonomiczne.

Vissak, T., Vadi, M. (2013). (Dis)honesty in management. UK: Emerald, Bingley.

Cite this article as: Janowski, M. (2018). Ethical codes and their importance in the modern management processes. European Journal of Service Management, 3 (27/2), 183-188. DOI: 10.18276/ejsm.2018.27/2-22. 